\title{
IMPLEMENTASI KEBIJAKAN PELAYANAN ADMINISTRASI TERPADU KECAMATAN (PATEN) TERHADAP KUALITAS PELAYANAN PUBLIK DI KECAMATAN SIDIKALANG KABUPATEN DAIRI
}

\author{
Agustriani Susanti Manurung, Heri Kusmanto dan Usman Tarigan* \\ Pascasarjana Universitas Medan Area, Medan, Indonesia
}

Diterima Februari 2018; Disetujui April 2018; Dipublikasikan Juni 2018

\begin{abstract}
Abstrak
Tujuan dilaksanakannya penelitian ini adalah untuk mendeskripsikan mengenai tahapan dilaksanakan PATEN di Kecamatan Sidikalang, mengenai faktor-faktor yang berpengaruh terhadap pelaksanaan PATEN di Kecamatan Sidikalang. Dengan menggunakan metode deskriptif kualitatif, penelitian ini menghasilkan beberapa kesimpulan yaitu sosialisasi yang dilakukan baik antara pihak Kabupaten dengan pihak Kecamatan belum sepenuhnya merata dan belum mampu meningkatkan kesadaran masyarakat, kualitas dan kuantitas aparatur yang belum memadai, koordinasi antar instansi terkait baik itu pihak yang kepentingannya dipengaruhi khususnya kecamatan.. Berdasarkan hasil analisis penelitian, maka kecamatan memegang peranan penting sebagai pusat pelayanan yang paling dekat dengan masyarakat terutama daerah yang luas dan sulit dijangkau. Oleh karena itu selain adanya kewenangan yang luas sesuai dengan porsinya, maka kecamatan juga perlu didukung oleh dana, sarana prasarana serta aparatur yang memadai baik kuantitas maupun kualitasnya.
\end{abstract}

Kata Kunci : Implementasi Kebijakan, Pendelegasian Kewenangan, PATEN

\begin{abstract}
Purpose of the implementation of this study was to describe the stages held in the District PATEN Sidikalang, about the factors that affect the implementation Sidikalang PATEN in the district. By using qualitative descriptive method, this research resulted in several conclusions that socialization is done either between the district. Based on the analysis of research, the sub-district plays an important role as a service center that is closest to the people, especially over large areas and difficult to reach. Therefore, in addition to their broad discretion in accordance with its portion, then the sub-district also needs to be supported by the fund, infrastructure and adequate personnel both quantity and quality.
\end{abstract}

Keywords: Policy Implementation, Delegation of Authority, PATENTS

How to Cite : Manurung, S.A, Kusmanto, H., dan Tarigan, U., 2018, Implementasi Kebijakan Pelayanan Administrasi Terpadu Kecamatan (Paten) Terhadap Kualitas Pelayanan Publik Di Kecamatan Sidikalang Kabupaten Dairi 6 (1): 47-57
${ }^{*}$ Corresponding author:
P-ISSN-2549-9165
E-mail: agustriani@gmail.com
e-ISSN -2580-2011 


\section{Pendahuluan}

Pelayanan publik yang berkualitas menjadi salah satu wujud dari ciri tata pemerintahan yang baik (good governance). Kinerja pelayanan publik sangat besar pengaruhnya terhadap kualitas kehidupan masyarakat. Oleh karena itu, membangun sistem manajemen pelayanan publik yang handal adalah kewajiban bagi Daerah untuk meningkatkan kesejahteraan warganya.Tidak mengherankan kalau perbaikan kualitas pelayanan publik menjadi salah satu alasan mengapa Pemerintah mendesentralisasikan kewenangan penyelenggaraan pelayanan publik kepada Daerah.

Dengan menyerahkan kewenangan penyelenggaraan pelayanan kepada daerah diharapkan agar pelayanan publik akan menjadi lebih responsive atau tanggap terhadap dinamika masyarakat di daerahnya.

Sebagaimana diamanatkan UndangUndang Nomor 25 Tahun 2009 tentang Pelayanan Publik, dimana Pelayanan Publik ialah kegiatan atau rangkaian kegiatan dalam rangka pemenuhan kebutuhan pelayanan sesuai dengan peraturan perundang-undangan bagi setiap warga negara dan penduduk atas barang, jasa dan/ atau pelayanan administratif yang disediakan oleh penyelenggara pelayanan publik. Dalam hal ini, penyelenggara pelayanan publik diamanatkan untuk terus meningkatkan kualitas dalam rangka menjamin kesederhanaan, kemudahan, keterjangkauan, dan memberikan manfaat kepada masyarakat. Terkait dengan pelayanan terhadap publik/masyarakat ini, didalam Peraturan Pemerintah Nomor 38 Tahun 2007 tentang Pembagian Urusan Pemerintahan antara Pemerintah, Pemda Provinsi, Pemda Kab/Kota, pada Pasal 7 Ayat (1) ditetapkan urusan pemerintahan yang wajib diselenggarakan oleh Pemerintah Daerah Provinsi, Pemda Kabupaten/Kota berkaitan dengan pelayanan dasar. Pelayanan publik menjadi suatu tolok ukur kinerja pemerintah yang paling kasat. Masyarakat dapat langsung menilai kinerja pemerintah berdasarkan kualitas layanan publik yang diterima, karena kualitas layanan publik menjadi kepentingan banyak orang dan dampaknya langsung dirasakan oleh masyarakat dari semua kalangan, dimana keberhasilan dalam membangun kinerja pelayanan publik secara professional, efektif, efisien, dan akuntabel akan mengangkat citra positif pemerintah di mata warga masyarakatnya.

Fokus utama kebijakan publik dalam negara modern adalah pelayanan publik, yang merupakan segala bentuk jasa pelayanan, baik dalam bentuk barang maupun jasa publik yang pada prinsipnya menjadi tanggung jawab dan dilaksanakan 
oleh negara untuk mempertahankan atau meningkatkan kualitas kehidupan orang banyak (Wikipedia, 2008). Dalam pelaksanaannya, kebijakan pelayanan publik ini harus diturunkan dalam serangkaian petunjuk pelaksanaan dan petunjuk teknis yang berlaku internal dalam birokrasi. Sedangkan dari sisi masyarakat, yang penting adalah adanya standar pelayanan publik, yang menjabarkan pada masyarakat apa pelayanan yang menjadi haknya, siapa yang bias mendapatkannya, apa persyaratanny, juga bagaimana bentuk layanan itu.

Berbicara pelayanan publik, salah satu penerapan dan bukti nyata yang terjadi dilapangan adalah adanya suatu program yang dikeluarkan pemerintah melalui Peraturan Menteri Dalam Negeri Nomor 4 Tahun 2010 tentang Pedoman Pelayanan Administrasi Terpadu Kecamatan (PATEN). PATEN dibentuk dengan maksud untuk mewujudkan Kecamatan sebagai pusat pelayanan masyarakat dan menjadi simpul pelayanan bagi kantor/badan pelayanan terpadu di kabupaten/kota. Sedangkan tujuan didirikan PATEN berdasarkan PERMENDAGRl Nomor 4 Tahun 2010 yaitu untuk meningkatkan kualitas dan mendekatkan pelayanan kepada masyarakat dengan penyelenggara PATEN adalah pihak Kecamatan yang terdiri dari
Camat, Sekretaris Kecamatan beserta Kepala Seksi yang membidangi pelayanan administrasi tersebut. Serta pendelegasian sebagian kewenangan meliputi bidang perizinan dan non perizinan.

PATEN merupakan suatu inovasi pelayanan guna mendekatkan jarak antara pemerintah sebagai penyedia layanan dengan masyarakat sebagia penerima layanan, yang sejatinya didasari oleh adanya pendelegasian kewenangan dari Bupati kepada Camat. Adapun beberapa syarat yang harus dipenuhi agar suatu Kecamatan dapat dijadikan sebagai penyelenggara PATEN (berdasarkan Permendagri Nomor 4 Tahun 2010), yaitu: Syarat Substantif, yaitu adanya pendelegasian kewenangan dari Bupati/Walikota kepada Camat yang meliputi bidang perizinan dan non perizinan yang ditetapkan melalui Peraturan Bupati/Walikota;

Syarat Administratif, yang meliputi adanya standar pelayanan dan uraian tugas personil kecamatan yang ditetapkan melalui Peraturan Bupati/Walikota;

Syarat Teknis, yang meliputi sarana dan prasarana, serta adanya pelaksana teknis yang disesuaikan dengan kemampuan anggaran daerah

$$
\text { Pada tingkat Kabupaten/Kota, }
$$
struktur pemerintahan yang menjadi subordinasi pemerintah kabupaten/kota adalah pemerintahan kecamatan. 
Pemerintahan ditingkat kecamatan secara penuh kepada daerah menjadi lebih dibutuhkan perannya kabupaten/kota dimaksudkan karena sebagai perpanjangan tangan Pemerintah daerah itu lebih dekat kepada masyarakat Daerah dalam memberikan pelayanan sebagai pihak yang dilayani dan publik kepada masyarakat.

Kecamatan merupakan lembaga diberdayakan. Asumsinya semakin dekat jarak antara pelayan dan yang dilayani yang strategis dalam mengelola dan maka pelayanan akan sesuai dengan melayani kepentingan masyarakat. harapan masyarakat. Apabila pelayanan Kecamatan merupakan sebuah organisasi sesuai dengan harapan masyarakat maka yang hidup dan melayani kehidupan masyarakat. Dalam menjamin tugas-tugas pemerintahan seperti penyelenggaraan pemerintahan, pembangunan, kemasyarakatan termasuk didalamnya melaksanakan tugas pelayanan serta melaksanakan tugas yang didelegasikan oleh Bupati/Walikota.

Kecamatan merupakan line office dari pemerintah daerah yang berhadapan langsung dengan masyarakat dan mempunyai tugas membina desa/kelurahan. Kualitas pelayanan di Kecamatan diharapkan akan menjadi lebih baik setelah menjadi perangkat daerah dibandingkan pada saat sebagai perangkat dekonsentrasi yang pengaturannnya sangat sentralistik. Sebab tujuan pemberian otonomi daerah dan keberadaan daerah adalah untuk mensejahterahkan masyarakat melalui pemberdayaan dan penyediaan pelayanan publik secara efektif, efisien, ekonomis dan demokratis (Suwandi, 2002).Oleh karena itu, pemberian kewenangan pemerintahan diharapkan kualitas pelayanan akan menjadi lebih baik.

Dengan demikian pembentukan suatu perangkat daerah bertujuan untuk meningkatkan kesejahteraan masyarakat dan apabila dihubungkan dengan tujuan tersebut, maka perubahan apapun atas status kecamatan seharusnya bertujuan untuk meningkatkan efektivitas organisasi kecamatan dalam pelayanan publik.

Pada tataran dibawahnya, Peraturan Pemerintah Nomor 19 Tahun 2008 tentang Kecamatan ditegaskan bahwa tugas Camat bahwa meliputi antara lain melakukan perencanaan kegiatan pelayanan kepada masyarakat di Kecamatan dan melakukan percepatan pencapaian standar pelayanan minimal di wilayahnya, dimana Camat hanya menerima pelimpahan sebagian wewenang Bupati/Walikota untuk menangani sebagian urusan otonomi daerah, dengan tujuan untuk memangkas birokrasi sekaligus meningkatkan mutu pelayanan kepada masyarakat. Dengan kata lain, 
ternyata luas-tidaknya wewenang yang didelegasikan kepada Camat sangat dipengaruhi oleh political will dan komitmen dari Bupati/Walikota dalam meredam conflict of interest antar perangkat daerah. Di sisi lain diterbitkannya beberapa peraturan tentang penyelenggaraan pelayanan secara tidak langsung juga turut melemahkan posisi strategis kecamatan sebagai yang terdepan dalam hal pelayanan publik, sehingga kecamatan hanya disibukkan oleh kewenangan administratif dan seremonial belaka.

Dalam hal Pelimpahan Wewenang dari Bupati kepada Camat yang diatur dalam Peraturan Bupati Dairi Nomor 18 Tahun 2010 (Pasal 6) tentang Pelimpahan Wewenang Bupati Kepada Camat, jenis pelayanan dari bidang perizinan terdiri dari: Pemberian izin gangguan; Pemberian izin mendirikan bangunan untuk rumah tinggal tanpa tingkat seluas maksimal 200 (dua ratus) meter persegi diluar ibukota kecamatan, dan Pemberian izin pertunjukan hiburan, sedangkan urusan lainnya ditangani oleh pihak Kabupaten yang dalam hal ini baik dinas/badan ataupun kantor yang terkait dalam hal pemberian izin ataupun yang saling berkoordinasi dengan pihak kecamatan mengenai masalah perizinan. Penulis mencontohkan dalam hal mengenai masalah perizinan seperti dalam hal penanganan izin mendirikan bangunan. Dimana dalam proses penanganan berkasnya tidak selesai ditingkat kecamatan melainkan harus melibatkan pihak Kabupaten (dalam hal ini mengikutsertakan Dinas Penanaman Modal dan Perizinan Terpadu). Yang dalam hal ini, diharapkan segala urusan mengenai penanganan izin mendirikan bangunan dapat diselesaikan langsung di Kecamatan, tanpa harus merepotkan masyarakat yang ingin melakukan urusan izin mendirikan bangunan tersebut.

Hal ini membuat pelayanan yang diberikan menjadi tidak maksimal dan tidak berpusat, maka muncullah sebuah kecenderungan sentralisasi penyelenggaraan pelayanan yang hanya berpusat pada pihak Kabupaten saja, sementara dalam hal ini juga Camat sebagai penguasa wilayah, kehilangan wewenang yang bersifat strategis. Fakta ini menunjukkan sentralisasi pelayanan disatu sisi memang bermuara positif (efektivitas dan efisiensi pelayanan), tetapi disisi lain malah menjauhkan pelayanan publik dari masyarakat sekaligus terabaikannya posisi strategis kecamatan.

Bagi Kabupaten/Kota yang tidak luas serta dilengkapi fasilitas transportasi yang memadai, dimana jika dipusatkan di Kantor Pelayanan Pereizinan Terpadu memungkinkan dan cukup ideal, sedangkan dipihak lain model yang 
dipusatkan di Kantor Pelayanan Perizinan Terpadu dengan wilayah Kabupaten/Kota yang cukup luas dengan akses transportasi yang masih minim, dimana jarak yang ditempuh jauh, tentu akan memberatkan bagi masyarakat dalam hal pengurusannya seperti dalam hal biaya, energi dan waktu.

Perubahan pemahaman yang memposisikan pemerintah daerah sebagai pelayan masyarakat, sudah selayaknya diikuti oleh revitalisasi kecamatan sebagai salah satu unit pelayanan terdekat dengan masyarakat. Hal ini penting karena jika kewenangan dibiarkan terkonsentrasi di tingkat kabupaten/kota, maka akan ditemukan paling tidak dua permasalahan. Pertama, pelayanan kepada masyarakat menjadi kurang efektif sebagai akibat dari beban kerja yang terlalu berat (overload) sehingga format kelembagaan organisasi kabupaten/kota akan membengkak. Kedua, kecamatan sebagai perangkat daerah akan muncul sebagai organisasi dengan fungsi minimal. Apabila kecamatan hanya melakukan tugas-tugas rutin administrasi saja, maka hal ini adalah pemborosan (Afrizal J., 2008).Untuk mencegah pemborosan akibat fungsi yang minimal tersebut, maka perlu dilakukan desentralisasi pelayanan publik melalui pendelegasian kewenangan.Oleh karena itu, khusus untuk pelayanan yang sederhana, mudah, cepat serta tanpa membutuhkan prasyarat teknis tinggi, sudah sepantasnya cukup diselenggarakan oleh kecamatan sebagai Pusat Pelayanan Masyarakat (PUSYANMAS) (Wasistiono, Nurdin, dan Fahrurozi, 2009).

Terkait dengan Penelitian ini terdapat berbagai permasalahan yang dihadapi oleh Pemerintah Kecamatan Sidikalang dalam hal mengimplementasikan kebijakan PATEN tersebut. Diantaranya terdapat kapasitas dan kuantitas personil belum sesuai harapan, koordinasi antar instansi terkait penyelenggaraan pelayanan, serta berbagai permasalahan yang berkaitan dengan partisipasi masyarakat dalam penyelenggaraan PATEN di Kecamatan. Selain itu, juga terdapat berbagai permasalahan lain seperti kurang tanggapnya pegawai dalam penyelenggaraan PATEN, sarana dan prasarana yang kurang mendukung dan kurangnya keterbukaan informasi mengenai penyelenggaraan PATEN dikalangan masyarakat. Yang menjadi tujuan penelitian tersebut ialah: untuk mengetahui dan menganalisis, bagaimana proses implementasi kebijakan mengenai Pelayanan Administrasi Terpadu Kecamatan (PATEN) yang terjadi di Kecamatan Sidikalang dalam hal meningkatkan kualitas pelayanan publik.

Untuk mengetahui dan menganalisis, kendala apa yang dihadapi oleh Kecamatan Sidikalang dalam rangka implementasi 
kebijakan Pelayanan Administrasi Terpadu Kecamatan (PATEN) dalam meningkatkan kualitas pelayanan publik

\section{Metode Penelitian}

Dalam Penelitian ini, pendekatan yang digunakan adalah penelitian kualitatif, karena penelitian ini bertujuan untuk memahami fenomena implementasi Kebijakan PATEN di Kecamatan Sidikalang Kabupaten Dairi melalui dukungan datadata kualitatif (hasil wawancara mendalam, observasi, studi kepustakaan dan dokumentasi), namun penggunaan data kuantitatif juga dimungkinkan sebagai pelengkap informasi yang digunakan dalam analisis setiap pertanyaan penelitian.

Penelitian ini dilakukan di Kecamatan Sidikalang Kabupaten Dairi. Adapun informan penelitian ini adalah:

Sebagai Stakeholder kunci adalah : Asisten Administrasi Umum Setda Kab. Dairi;

Sebagai Pihak pendukung implementasi kebijakan adalah : Kepala Bagian Tata Pemerintahan Setda Kabupaten Dairi dan Kepala Dinas Penanaman Modal dan Pelayanan Perizinan Terpadu Satu Pintu Kabupaten Dairi;

$\begin{array}{ccr}\text { Berdasarkan } & \text { posisi } & \text { yang } \\ \text { dipertimbangkan } & \text { oleh } & \text { pengambil } \\ \text { keputusan, maka selaku satuan } & \text { kerja teknis }\end{array}$

yang membidangi : Camat Kecamatan Sidikalang dan Sekcam Kecamatan Sidikalang;

Stakeholder yang berperan sebagai pendukung kebijakan tersebut adalah : Staf pada Kantor Kecamatan Sidikalang yang menangani PATEN beserta beberapa perwakilan masyarakat yang menerima pelayanan PATEN di Kantor Kecamatan Sidikalang.

Sedangkan teknik pengumpulan data yang digunakan antara lain: Observasi dan Studi Lapangan; Wawancara; Studi Kepustakaan dan dokumen kualitatif; dan yang terakhir dengan Audio dan Visual.

\section{Pembahasan}

\section{Komunikasi}

Implementasi akan berjalan efektif apabila ukuran-ukuran dan tujuan-tujuan kebijakan dipahami oleh individu-individu yang bertanggungjawab dalam pencapaian tujuan kebijakan. Kejelasan ukuran dan tujuan kebijakan dengan demikian perlu dikomunikasikan secara tepat dengan para pelaksana.Konsistensi atau keseragaman dari ukuran dasar dan tujuan perlu dikomunikasikan sehingga implementor mengetahui secara tepat ukuran maupun tujuan kebijakan itu.

Komunikasi dalam organisasi
merupakan suatu proses yang amat
kompleks dan rumit. Seseorang bisa
menahannya hanya untuk kepentingan
tertentu, atau menyebarluaskannya.


Disamping itu sumber informasi yang berbeda juga akan melahirkan interprestasi yang berbeda pula. Agar implementasi berjalan efektif, siapa yang bertanggungjawab melaksanakan sebuah keputusan harus mengetahui apakah mereka dapat melakukannya.Sesungguhnya implementasi kebijakan harus diterima oleh semua personil dan harus mengerti secara jelas dan akurat mengenai maksud dan tujuan kebijakan. Dalam hal Komunikasi yang diterapkan pada tahap Implementasi Kebijakan PATEN tersebut adalah dengan cara Sosialisasi.

\section{Sumber Daya}

Komponen sumber daya ini meliputi jumlah staf, keahlian para pelaksana, informasi yang relevan dan cukup untuk mengimplementasikan kebijakan dan pemenuhan sumber-sumber terkait dalam pelaksana program, adanya kewenangan yang menjamin bahwa program dapat diarahkan kepada sebagaimana yang diharapkan, serta adanya fasilitas-fasilitas pendukung yang dapat dipakai untuk melakukan kegiatan program seperti dana dan prasarana.

\section{Disposisi}

Berbicara Disposisi berarti berbicara sikap/respon implementor terhadap kebijakan yaitu berupa kesadaran pelaksana, petunjuk/arahan pelaksana untuk merespon program kearah penerimaan atau penolakan, dan intensitas dari respon tersebut. Para pelaksana mungkin memahami maksud dan sasaran program namun seringkali mengalami kegagalan dalam melaksanakan program secara tepat karena mereka menolak tujuan yang ada di dalamnya sehingga secara sembunyi mengalihkan dan menghindari implementasi program. Disamping itu dukungan para pejabat pelaksana sangat dibutuhkan dalam mencapai sasaran program.

\section{Struktur Birokrasi}

Struktur Birokrasi adalah karakteristik, norma-norma dan pola-pola hubungan yang terjadi berulang-ulang dalam badan-badan eksekutif yang mempunyai hubungan baik potensial maupun nyata dengan apa yang mereka miliki dalam menjalankan kebijakan. Salah satu dari aspek struktur yang penting dari setiap organisasi adalah adanya prosedur operasi yang standar (standard operating procedures atau SOP). SOP menjadi pedoman bagi setiap implementor dalam bertindak.

Kendala Yang Dihadapi Kecamatan Sidikalang Dalam Mengimplementasikan Kebijakan PATEN

1. Komunikasi

Dari Segi Komunikasi yaitu Sosialisasi. Dimana Sosialisasi yang dilakukan tidak merata sehingga hanya sebagian masyarakat saja yang mengetahui tentang program PATEN tersebut. 


\section{Sumber Daya}

Dilihat dari segi Sumber Daya Manusia dimana terdapat keterbatasan jumlah personil baik dari segi kuantitas maupun dari segi kualitas sedangkan jika dilihat dari Sumber Dana yang menjadi kendala yaitu kekurangan dana dalam hal penyelenggaraan program PATEN tersebut.

\section{Kesimpulan}

Sosialisasi yang dilakukan dari Pihak Kabupaten yang bekerjasama dengan pihak Kecamatan mengenai program PATEN tersebut belum sepenuhnya merata dan belum mampu meningkatkan kesadaran masyarakat. Kualitas dan Kuantitas aparatur Kecamatan yang belum memadai dalam melaksanakan PATEN.

Koordinasi antar instansi terkait baik itu pihak yang kepentingannya dipengaruhi khususnya kecamatan dengan DPM\&PTSP, belum terlaksana secara maksimal dan cenderung berjalan sendirisendiri. Kedudukan Pembuat kebijakan yang ditujukan dengan adanya political will dan komitmen Bupati Dairi dalam mengawali implementasi kebijakan PATEN.

Komitmen untuk membenahi penyelenggaraan pelayanan publik yang dimiliki oleh Bupati Dairi belum terinternalisasi secara komprehensif hingga kepada para staf (frontliner) yang ada di Kecamatan, karena masih ditemukan penyimpangan dalam pungutan liar ataupun adanya calo yang berkeliaran.

\section{DAFTAR PUSTAKA}

Abidin, 2006, Kebijakan Publik, Jakarta: Suara Bebas.

A.S. Moenir, Manajemen Pelayanan Umum di Indonesia, Jakarta: Bumi Aksara.

Dunn, William N., 2003, Pengantar Analisis Kebijakan Publik - edisi kedua, diterjemahkan kedalam Bahasa Indonesia oleh Samudra Wibawa, dkk.

Dwiyanto, Agus, 2011, Manajemen Pelayanan Publik: Peduli, Inklusif, dan Kolaboratif (edisikedua), Yogyakarta: Gajah Mada Press.

Dye, Thomas R. 1975.Understanding Public Policy. Englewood Cliff, N.].: Prinntice-Hall $2^{\text {nd }}$ ed.

Edward 111, George C, 1980, Implementing Public Policy, Wahington: Congressional Quanterly, lnc.

Eko, Prasojo, Aditya Perdana dan Nor Hiqmah, 2006.Kinerja Pelayanan Publik, Presepsi masyarakat terhadap Kinerja, Keterlibatan dan Partisipasi Masyarakat dalam Pelayanan Bidang Pendidikan, Kesehatan dan Kependudukan, YAPPIKA. Jakarta.

Hardiansyah, 2011, Kualitas Pelayanan Publik - Konsep.Dimensi, Indikator, 
dan Imlementasinya, Yogyakarta: Gava Media.

Hogwood, Brian W. dan Lewis A. Gunn, 1993, Policy Analysis For The Real World, Oxford: Oxford University Press.

Labolo, Muhaddan, 2012, Memperkuat Pemerintahan Mencegah Negara Gagal - Sebuah Ikhtiar Mewujudkan Good Governance dan Negara Kesejahteraan, Jakarta: Kubah Ilmu.

Lester, James r. dan Joseph Stwart, jr, 2000, Public Policy - $A n$ Evolutionary Approach, second edition, Belmont USA: Wadsworth/ Thomson Learning.

Mulyadi, Edi, 2016, Studi Kebijakan Publik dan Pelayanan Publik :Konsep dan Aplikasi Konsep Kebijakan Publik Berbasi sAnalisi sBukti Untuk Pelayanan Publik, Bandung : Alfabeta.

Nugroho, Riant, 2011, Public Policy Dinamika Kebijakan, Analisis Kebijakan, Manajemen Kebijakan, Jakarta :Elex Media Komputindo.

Parson Wayne, 2005, Public Policy, Prenada Media, Jakarta.

Prasojo, 2009, ReformasiKedua Melanjutkan Estafet Reformasi, Jakarta: Salemba Humanika.

Ripley, Randall B. and Grace A. Franklin. 1982. Bureeaucracy and Policy
Implementation. Homewood, Illinois: The Dorsey Press.

Santoso, Amir.1993. Analisis Kebijakan Publik: Suatu Pengantar. Jurnal Ilmu Politik 3. Jakarta: Gramedia.

Savas, E.S., 1987, Privatization - The Key to Better Government, Chatam New Jersey. Chatam House Publisher.

Smith, B.C., 1985, Decentralization :The Territorial Dimention of State, London: George Allen \&Unwim Publisher Ltd.

Tahir, Arifin, 2015, Kebijakan Publik dan Transparansi Pemerintahan Daerah, Bandung :Alfabeta.

Tangkilisan, HeselNogi. 2003. Implementasi Kebijakan Publik: Transformasi Pikiran George III. Yogyakarta :Lukman Offset YPAPL.

Wasistioni, Sadu, Ismail Nurdin, dan M. Fahrurozi, 2009, Perkembangan Organisasi Kecamatan dari masa ke masa, Lembaga Kajian Manajemen Pemerintahan Daerah (LKMPD), Bandung : Fokusmedia.

Winarno, Budi, 2014, Kebijakan Publik :Teori, Proses dan Studi Kasus, Jakarta : Center of Academic Publishing Service

\section{Peraturan Perundang -Undangan:}

Undang - Undang Nomor 25 Tahun 2009 tentang Pelayanan Publik.

Peraturan Pemerintah Nomor 65 Tahun 2005 tentang Pedoman Penyusunan 
dan Penerapan Standar Pelayanan

Minimal, Lembaran Negara Republik

Indonesia Tahun 2005.

Peraturan Pemerintah Nomor 19 Tahun 2008 tentang Kecamatan.

Peraturan Menteri Dalam Negeri Nomor

24 Tahun 2006 tentang Pedoman Penyelenggaraan Pelayanan Terpadu Satu Pintu.

Permendagri Nomor 4 Tahun 2010 tentang Pedoman Pelayanan Administrasi Terpadu Kecamatan.

Peraturan Menteri Dalam Negeri Republik Indonesia Nomor 15 Tahun 2014 tentang Pedoman Standar Pelayanan.

Peraturan Menteri Dalam Negeri Republik Indonesia Nomor 24 Tahun 2014 tentang Pedoman Penyeleggaraan Pengaduan PelayananPublik.

Peraturan Bupati Dairi Nomor 26 Tahun 2014 tentang Standar Pelayanan Administrasi Terpadu Kecamatan di Kabupaten Dairi. 
Jurnal Ilmu Administrasi Publik 6 (1) (2018): 47-57 